\title{
Application of X-Ray Fluorescence Analysis for Forensic Science in Mongolia
}

\author{
*Bolortuya Damdinsuren ${ }^{1,2}$ and Zuzaan Purev' \\ ${ }^{1}$ Nuclear Research Center, ${ }^{3}$ National University of Mongolia, \\ University street-1, Ulaanbaatar 13330, Mongolia \\ ${ }^{2}$ Department of Materials Science and Engineering, Kyoto University, Sakyo-ku, Kyoto 606-8501, Japan \\ *Address for correspondence: Bolortuya Damdinsuren, E-mail: bolortuya_d9@num.edu.mn
}

Submitted 17 November 2017

We study the possibility of evaluating the elemental composition of automotive (vehicle) coating paints and determining the gunshot residue from $5.6 \mathrm{~mm}$ bullets of a small-caliber gun using the EDXRF technique. An Elvax EDXRF spectrometer, consisting of a Si-PIN detector with a resolution of $200 \mathrm{eV}$ for $\mathrm{MnK}_{\alpha}$ radiation with energy of $5.9 \mathrm{keV}$ and a mini X-ray tube with Rh anode, was used. Results of the study showed that the number of shots was directly correlated to the relative intensity of barium and lead on the gunshot target, and the distance of the shooting could be determined using chemical elements intensities, such as $\mathrm{Pb}, \mathrm{S}$, $\mathrm{Ba}$ and $\mathrm{Cu}$ intensities, from the gunshot residue. In the case of automotive paints, the elements identified in the samples were $\mathrm{Ca}, \mathrm{Ti}, \mathrm{Fe}, \mathrm{Cu}, \mathrm{Cl}, \mathrm{Zn}, \mathrm{Cr}$ and $\mathrm{Pb}$, and the EDXRF technique could be used for the identification of the different cars by the paint coating samples from the crashed car. This work was the first study which used the EDXRF analysis for automotive paints in Mongolia.

Key words: XRF, application in the forensic science, gunshot residue, automotive paint

\section{Применение рентгенофлуоресцентного анализа в криминалистике в Монголии}

\author{
*Д. Болортуяа ${ }^{1,2}$, П. Зузаан ${ }^{1}$ \\ ${ }^{1}$ Nuclear Research Center, ${ }^{3}$ National University of Mongolia, \\ University street-1, Ulaanbaatar 13330, Mongolia \\ ${ }^{2}$ Department of Materials Science and Engineering, Kyoto University, Sakyo-ku, Kyoto 606-8501, Japan \\ *Адрес для переписки: Bolortuya Damdinsuren, E-mail: bolortuya_d9@num.edu.mn
}

Поступила в редакцию 17 ноября 2017 г.

\begin{abstract}
Исследована возможность оценки элементного состава автомобильных лакокрасочных покрытий и определения химического состава остатков после выстрела из пистолета с пулями 5.6 мм с использованием технологии энергодисперсионного рентгено-фрлуоресцентного анализа (ЭДРФА). Использован спектрометр Elvax EDXRF, состоящий из Si-PIN-детектора с разрешением 200 эВ для излучения $\mathrm{MnK}_{\mathrm{\alpha}}$ с энергией 5.9 кэВ и мини-рентгеновской трубки с Rh-анодом. Для обработки спектра использовано программное обеспечение ELVAX. Результаты исследований показали, что количество выстрелов коррелирует с относительной интенсивностью излучения линий бария и свинца на огнестрельной мишени, а расстояние от огнестрельного оружия до цели можно определить, используя интенсивности некоторых химических элементов остатков выстрелов из огнестрельного оружия, таких как $\mathrm{Pb}, \mathrm{S}$, Ва и Сu. В случае автомобильных красок элементами, идентифицированными в образцах, оказались $\mathrm{Ca}, \mathrm{Ti}, \mathrm{Fe}, \mathrm{Cu}, \mathrm{Cl}, \mathrm{Zn}, \mathrm{Cr}$ и Pb, а метод ЭДРФА может использоваться для распознавания различных автомобилей по образцам лакокрасочного покрытия из разбитого автомобиля. Эта работа является первым исследованием, в котором использовался анализ ЭДРФА для автомобильных красок в Монголии.

Ключевые слова: РФА, применение в судебной медицине, остатки выстрелов огнестрельного оружия, автомобильная краска
\end{abstract}

In recent years, high sensitivity equipment such as atomic absorption spectroscopy (AAS), total reflection X-ray fluorescence analysis (TXRF) and scanning electron microscopy/energy dispersive X-ray spectrometry (SEM/EDX) are being used in forensic examinations to discover and carry out analyses to determine the ele- 
mental content and to conduct research on a microscopic trace or invisible traces in dry, liquid or solid materials at the crime scene. The examples of the materials of interest include soil, sand, biological organs, paint, surrounding soil, water, air, small parts inside the cell and virus, as well as fiber, clothes, hair, wool, cashmere, sand, rock and food. These investigations are being made in order to make a conclusion with a scientific basis by the requests of law enforcement organizations [1-5]. One of the analysis methods being used is an energy dispersive X-ray fluorescence analysis (EDXRF). It is a well-established analysis technique for the qualitative and quantitative identification of chemical elements in different samples, and it allows for accurate, fast, and non-destructive determination of the elemental composition [6-9].

In Mongolia, the first physics laboratory for the forensic examination was established in 1978, and an atomic absorption spectrometry and equipments of infrared and ultraviolet light were installed through the support of the German Democratic Republic. It can be considered that this has set a basis to develop the atomic and nuclear techniques for the forensic science in Mongolia. In 2008, an EDXRF spectrometer from ElvaTech Ltd (Kiev) was installed at the National Institute of Forensic Science (NIFS) in Ulaanbaatar, Mongolia. Nuclear Research Center (NRC) of National University of Mongolia (NUM) and NIFS have cooperated to develop several methods using the EDXRF spectrometry and to study the possibility of using them for forensic examinations [10-11]. Therefore, it can be said that these efforts have laid the foundation for determining the elemental composition of forensic materials using the XRF analysis.

In the present paper, a development of EDXRF technique for forensic examinations such as for evaluating the elemental composition of automotive coating paints and determining the gunshot residue from 5.6 $\mathrm{mm}$ bullets of a small caliber gun is described.

\section{EXPERIMENTS AND RESULTS}

Apparatus. For the current study, Elvax EDXRF spectrometer consisting of a Si-PIN detector with thermo-electrical cooling, with a resolution of $200 \mathrm{eV}$ at 5.9 $\mathrm{keV}$, and a mini X-ray tube ( $5 \mathrm{~W}$ power maximum) with $\mathrm{Rh}$ anode and air cooling system was used at the $\mathrm{Na}$ tional Institute of Forensic Examination, Mongolia.

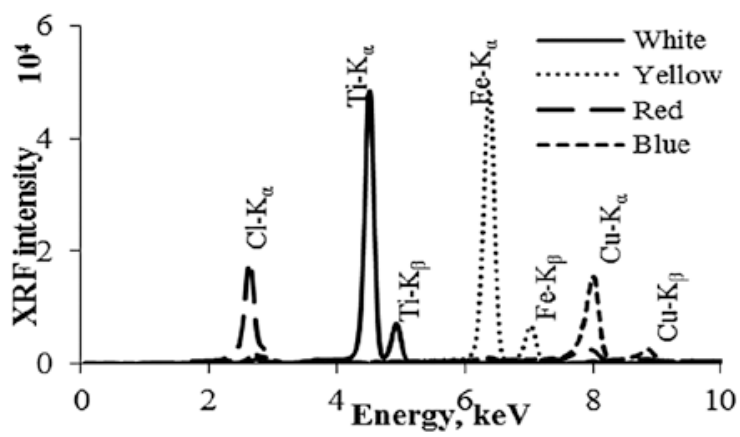

Figure 1. Comparison of white, yellow, red and blue paints' XRF spectra

\section{Study of automotive paints}

During the analysis of automotive paints in Mongolia, we have studied the possibility of evaluating the elemental composition of automotive coating paints using the EDXRF technique. Sliding contact among automobiles or between an automobile and another surface commonly produces smears. These chips of paints have been recognized as an important type of forensic evidence.

Sample Preparation. Samples of 16 main color paints and coatings were collected from about 20 cars of different makes. Paints samples were prepered by smoothly dyeing thin $3 \times 3 \mathrm{~cm}^{2}$ size polyester, which were then dried in ambient conditions for 2 days. And we directly used paint coatings from cars for the qualitative analysis.

In order to determine the elemental content of paints, ash samples of paints were prepared. We had chosen two paint samples which were $94.75 \mathrm{~g}$ white (code № $075)$ and $95.55 \mathrm{~g}$ red (code № 165) paints. These samples were burnt at inside burner at $600^{\circ} \mathrm{C}$ for 4 hours and then powdered to a particle size of around $70 \mathrm{mi}-$ cron by the agate pestle. Powder ash samples were prepared by pressing them into dedicatory container with 10 $\mathrm{mm}$ thickness, $20 \mathrm{~mm}$ diameter and $5 \mathrm{~mm}$ Mylar bottom.

Acquisition and Methods. The acquisition time was $100 \mathrm{~s}$, and XRF spectra were evaluated with the Elvax software package. The comparison of automotive paints spectra is shown in Figure 1.

From Figure 1, we can see the dependence of color of paints on the elemental composition. Furthermore, the pigments in paints may be approximately identified by their elemental indicators (Table 1) [2]. For example, the most common white pigment in use today is the titanium dioxide, and titanium value in white paint is the highest among other paints in the above Figure 1. Therefore, the main pigment of white paint (code № 075) may be the "titanium white".

Comparisons of coating samples from different white automobiles such as Accent, Kia Bongo and Nissan, and the white paint sample are shown in Figure 2. In Figure 2, titanium relative intensities in coating samples which were collected from the white cars

Table 1

Chemical compositions of coating samples from different automobiles [2]

\begin{tabular}{|c|c|c|}
\hline $\begin{array}{c}\text { Paint } \\
\text { Color }\end{array}$ & $\begin{array}{c}\text { Main } \\
\text { Element } \\
\text { Detected }\end{array}$ & $\begin{array}{c}\text { Pigments (and their identifying } \\
\text { elements) }\end{array}$ \\
\hline White & $\mathrm{Ti}$ & Titanium white (Ti) \\
\hline Blue & $\mathrm{Cu}$ & $\begin{array}{c}\text { Copper Phthalocyanine Blue (Cu, } \\
\text { possible Cl) }\end{array}$ \\
\hline Yellow & $\mathrm{Fe}, \mathrm{Zn}, \mathrm{Cr}$ & $\begin{array}{c}\text { Synthetic red and yellow oxides } \\
(\mathrm{Fe}), \text { Zinc tetroxychromate (Zn, Cr) }\end{array}$ \\
\hline Red & $\mathrm{Cl}, \mathrm{Fe}$ & $\begin{array}{c}\text { Synthetic red and yellow oxides } \\
\text { (Fe), Quinacridone pigments (red, } \\
\text { violet, gold) (Cl), Non-metallised } \\
\text { Azo Reds (Cl) }\end{array}$ \\
\hline
\end{tabular}




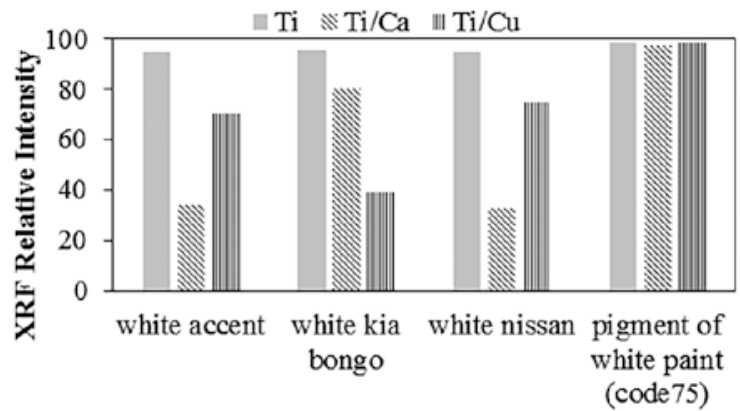

Figure 2. Comparison of coating samples from different white cars

have similar values. It was observed that these automobiles were painted by the white paint with titanium dioxide. However, intensity ratios of the $\mathrm{Ti} / \mathrm{Ca}$ and $\mathrm{Ti} /$ $\mathrm{Cu}$ have a different variety for each car. It was demonstarted that the EDXRF technique could be used for the identification of different cars by paint coating samples from the crashed car.

Determination of element content in the automotive paint. The elemental concentrations in the paint ash were calculated by the following formula [6]:

$$
C_{i}=I_{i}\left[k_{i}+\sum_{j} a_{i j} I_{j}\right]+B_{i}
$$

where $k_{i}$ and $a_{i j}$ are the correction coefficients, $B_{i}$ is the background term. The coefficients were determined by the least-squares fit on the basis of measured reference samples such as SG-2, soil-5, SP-2, SSL-1, SP-3 and other ash references $[12,13]$. The correction was done using the intensities rather than the concentrations. The algorithm assumed that the matrix effect of an element $j$ on the analyte $i$ is proportional to its intensity. The determination of a single element was possible using this equation.

The results of the calculated elemental contents by formula (1) were compared with chemical analyses in Table 2. Chemical analyses by standard methods were conducted at the Chemistry School of National University of Mongolia and Chemistry and Chemical Technology Institution of Mongolian Science Academy. From Table 2, the results of elemental contents determination by the developed method were fitting with the results of chemical analyses. It showed that the EDXRF technique could be used for the determination of chemical elements contents in the paint ash.

Table 2

Results comparison of minor elemental contents determination in paint ashes using EDXRF and chemical analysis

\begin{tabular}{|c|c|c|c|c|}
\hline \multirow{2}{*}{$\begin{array}{c}\text { Ele- } \\
\text { ments }\end{array}$} & \multicolumn{2}{|c|}{$\begin{array}{c}\text { Content in white paint } \\
\text { ash (\%) }\end{array}$} & \multicolumn{2}{c|}{$\begin{array}{c}\text { Content in red paint } \\
\text { ash (\%) }\end{array}$} \\
\cline { 2 - 5 } & EDXRF & $\begin{array}{c}\text { Chemi- } \\
\text { cal anal- } \\
\text { ysis }\end{array}$ & EDXRF & $\begin{array}{c}\text { Chemi- } \\
\text { cal anal- } \\
\text { ysis }\end{array}$ \\
\hline $\mathrm{Ca}$ & $1.02 \pm 0.16$ & & $0.43 \pm 0.04$ & \\
\hline $\mathrm{Fe}$ & $0.13 \pm 0.03$ & 0.16 & $0.46 \pm 0.02$ & 0.42 \\
\hline $\mathrm{Cu}$ & $0.0058 \pm 0.0007$ & 0.0040 & $0.33 \pm 0.02$ & 0.58 \\
\hline $\mathrm{Zn}$ & $0.0018 \pm 0.0002$ & & $0.28 \pm 0.04$ & \\
\hline
\end{tabular}

\section{Study of gunshot residues}

In this part, the possibility of gunshot residue determination from $5.6 \mathrm{~mm}$ bullets of small caliber guns, which are widely used in Mongolia, using the EDXRF technique have been studied.

Sample preparation and measurement. The samples for 80 bullets with $5.6 \mathrm{~mm}$ diameter were collected. First, shooting targets were prepared using the separated $12 \times 12 \mathrm{~cm}$ size cotton materials. Prepared targets were then shot by the small caliber gun from different distances including $0 \mathrm{~m}, 0.5 \mathrm{~m}, 1 \mathrm{~m}, 1.5 \mathrm{~m}$ and 2 $\mathrm{m}$. Shootings of 1 to 4 times from each distance were done after cleaning the gun hole. After each shot, the study targets were directly measured by Elvax EDXRF spectrometer for the qualitative analysis. Measurement time was $200 \mathrm{~s}$, and their spectrums were evaluated by Elvax software.

Gunshot residue results. In order to evaluate the elemental profile of a gunshot residue, we first assured that all the detectable elements that were present could be observed. An XRF spectrum of a gunshot target is shown in Figure 3, which indicated the presence of chemical elements such as $\mathrm{Cl}, \mathrm{K}, \mathrm{Ca}, \mathrm{Ti}, \mathrm{Cr}, \mathrm{Fe}, \mathrm{Cu}$, $\mathrm{Zn}$ and $\mathrm{Pb}$ in the gunshot target. Correlations of relative intensities of $\mathrm{Pb}, \mathrm{S}$ and $\mathrm{Ba}$ in gunshot targets and distances of the shootings are shown in Figure 4.

Linear correlation of relative intensity of chemical elements and shooting distance is shown in the above figure, and the values of lead and barium are the highest among other chemical elements in the gunshot targets.

Furthermore, Figure 5 demonstrates the dependence of shooting frequency for each distance from the relative intensity of $\mathrm{Pb}$ and $\mathrm{Ba}$.

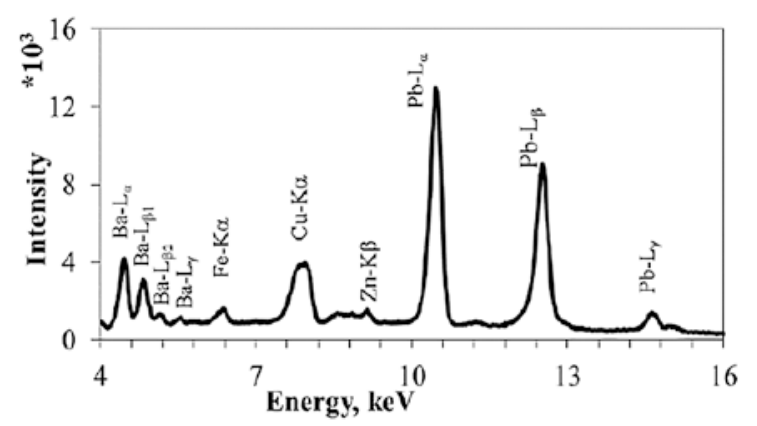

Figure 3. XRF spectrum of a gunshot target

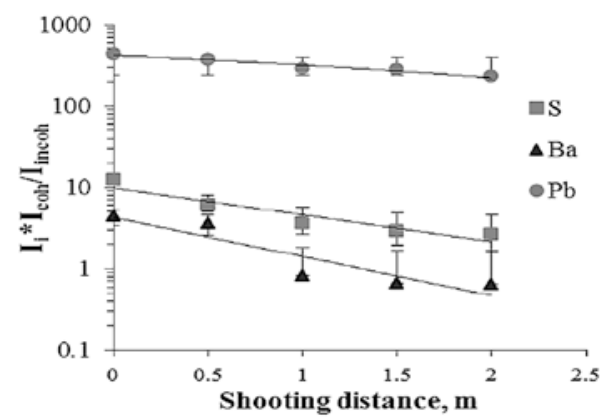

Figure 4. Correlation between relative $\mathrm{Pb}, \mathrm{S}$ and Ba intensity in gunshot targets and the distance of the shooting 


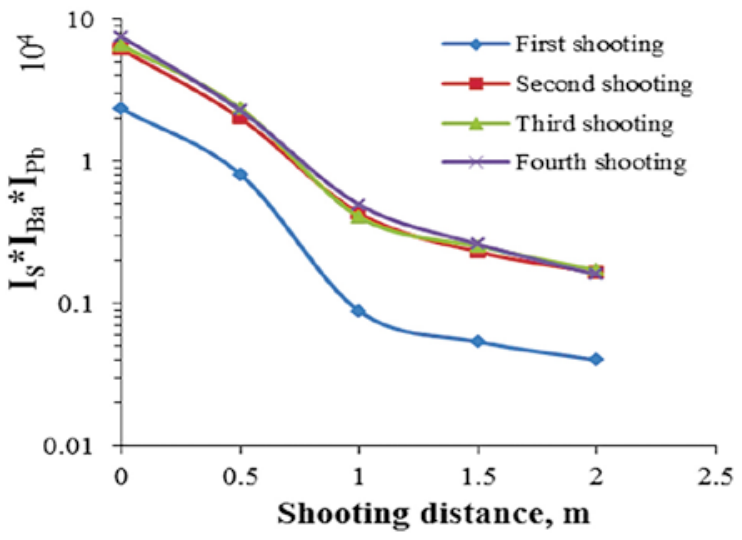

Figure 5. Correlation between the shooting distance and the relative intensities depending on the frequency

The study of the gunshot residue showed that the number of shootings is directly correlated with relative intensities of barium and lead on the gunshot target, and the distance of the shooting could be determined using several chemical elements intensity in gunshot targets such as $\mathrm{Pb}, \mathrm{S}$, and $\mathrm{Ba}$.

\section{Conclusion}

The results of the above studies showed that the EDXRF spectrometer could be used for the applicable crime investigations in Mongolia for the determination of chemical elements contents in coating samples, identification of different colored automotive paints and assist with the study of gunshot residue by small caliber guns.

\section{Acknowledgements}

The authors are grateful to Mr. E. Tuvshin-Erdene who is the head of Physics Laboratory, National Institute of Forensic Science, and to all of the participants in the study, especially to S. Battsetseg and B. Ulziitogtokh from nuclear technology groups in National University of Mongolia.

\section{References}

1. X-Ray Spectrometry in Forensic Science. Special Issue. X-Ray Spectrom. Ed. by M. J. Bailey. 2014, vol. 43, no. 1, pp. 1-66.

2. Forensic Examination of Glass and Paint: Analysis and Interpretation. Ed. by B. Caddy, CRC Press, 2001. 304 p.

3. Revenko A.G. [Review of the Special Issue of "X-Ray Spectrometry" - "X-Ray Spectrometry in Forensic Science"]. Analitika i Kontrol ' [Analytics and Control], 2014, vol. 18, pp. 112116 (in Russian). doi: 10.15826/analitika.2014.18.1.013

4. Kazimirov V.I., Zorin A.D., Zanozina V.F. Application of $X$-ray Fluorescence Analysis to Investigation of the Composition of Gunshot Residues. Journal of Applied Spectroscopy, vol. 73, no. 3, pp. 359-365. doi: 10.1007/s10812-006-0083-3 5. Revenko A.G. [Possibilities of Application X-Ray Fluorescence Analysis in Forensic Science]. Book of the $2^{\text {nd }}$ All Russian Conference on Analytical Spectroscopy. 2015. Krasnodar. Russia. 2015, p. 157 (in Russian).

6. Zuzaan P., Sodnom N., Dalkhsuren B., Gerbish Sh. Application in XRF technique. News of Mongolian Science Academy, 1984, vol. 4, pp. 22-29.
7. Fonseca J.F., Cruz M.M., Carvalho M.L. Muzzle-to-target distance determination by X-ray fluorescence spectrometry. X-Ray Spectrom., 2014, vol. 43, pp. 49-55. doi: 10.1002/xrs.2497 8. Sitko R., Zawisza B. Quantification in X-Ray Fluorescence Spectrometry. X-Ray Spectroscopy, InTech, 2012, pp. 137162. doi: $10.5772 / 29367$

9. Schwoeble A.J., Exline D.L. Current Methods in Forensic Gunshot Residue Analysis, CRC Press, 2000, 192 p.

10. Bolortuya D., Zuzaan P. Application of X-ray Fluorescence Analysis for Forensic Science in Mongolia. Book of the 4th Intern. Conf. on X-ray Analysis. 8-12 June 2015. Ulaanbaatar, Mongolia. 2015, pp. 27-28.

11. Ulziitogtokh B., Bolortuya D., Tuvshin-Erdene Kh., XRF Analysis of Gunshot Residue. Book of the 4th Intern. Conf. on X-ray Analysis. 8-12 June 2015. Ulaanbaatar, Mongolia. 2015, p. 78.

12. Lontsikh S.V., Petrov L.L. Standartnye obraztsy sostava prirodnykh sred [Reference Samples of Composition of Natural Materials]. Nauka: Novosibirsk. 1988. 273 p. (In Russian). 13. Govindaraju K. Compilation of working values and sample description for 383 geostandards. Geostand. Newslett, 1994, vol. 18, Spec. Issue, pp. 1-158.

\section{ЛИТЕРАТУРА}

1. X-Ray Spectrometry in Forensic Science. Special Issue. X-Ray Spectrom. Ed. by M. J. Bailey. 2014. V. 43, №. 1. P. 1-66. 2. Forensic Examination of Glass and Paint: Analysis and Interpretation / Ed. by B. Caddy, CRC Press, 2001. 304 p.

3. Ревенко А.Г. Рецензия на специальный выпуск журнала "X-ray spectrometry" - "рентгеновская спектрометрия в криминалистике // Аналитика и контроль. 2014. Т. 18, № 1. С. 112-116.

4. Казимиров В.И., Зорин А.Д., Занозина В.Ф. Применение рентгенофлуоресцентного анализа для исследования состава продуктов выстрела // Ж. приклад. спектроскопии. 2006. Т. 73, № 3. С. 320-325

5. Ревенко А.Г. Возможности применения рентгенофлуоресцентного анализа в криминалистике // II Всероссийская конференция по аналитической спектроскопии с международным участием (Краснодар, 27 сентября - 3 октября 2015 г.). Краснодар, 2015. С. 157.

6. Zuzaan P., Sodnom N., Dalkhsuren B., Gerbish Sh. Application in XRF technique // News of Mongolian Science Academy. 1984. V. 4. P. 22-29.

7. Fonseca J.F., Cruz M.M., Carvalho M.L. Muzzle-to-target distance determination by $X$-ray fluorescence spectrometry // X-Ray Spectrom. 2014. V. 43. P. 49-55.

8. Sitko R., Zawisza B. Quantification in X-Ray Fluorescence Spectrometry // X-Ray Spectroscopy. InTech, 2012. P. 137-162. 9. Schwoeble A.J., Exline D.L. Current Methods in Forensic Gunshot Residue Analysis. CRC Press, 2000. 192 p.

10. Bolortuya D., Zuzaan P. Application of X-ray Fluorescence Analysis for Forensic Science in Mongolia // Book of the 4th Intern. Conf. on X-ray Analysis. 8-12 June 2015. Ulaanbaatar, Mongolia. 2015. P. 27-28.

11. Ulziitogtokh B., Bolortuya D., Tuvshin-Erdene Kh. XRF Analysis of Gunshot Residue // Book of the 4th Intern. Conf. on X-ray Analysis. 8-12 June 2015. Ulaanbaatar, Mongolia. 2015. P. 78.

12. Лонцих С.В., Петров Л.Л. Стандартные образцы состава природных сред. Новосибирск: Наука, 1988. 273 с. 13. Govindaraju K. Compilation of working values and sample description for 383 geostandards // Geostand. Newslett. 1994. V. 18, Spec. Issue. P. 1-158. 